\title{
Pemanfaatan Sensor Inframerah untuk Input Kontrol Prediktif Temperatur pada Mesin Air Conditioning (AC) secara Wireless
}

\author{
Rofan Aziz*, Agung Kamaluddin, dan Karsid \\ Control, Instrumentation and Smart Energy Management Research Group (CISEMAR), \\ Politeknik Negeri Indramayu, Jawa Barat, Indonesia. \\ *Corresponding author, e-mail: rofan.aziz@polindra.ac.id
}

\begin{abstract}
Abstrak - Mesin pendingin ruangan (AC) semakin lazim digunakan sehingga konsumsi energi dari AC mendominasi kebutuhan energi pada gedung. Penelitian ini bertujuan untuk mengurangi konsumsi energi AC dengan cara mempertahankan suhu ruangan antara $22,8^{\circ} \mathrm{C}$ sampai $27,1^{\circ} \mathrm{C}$ menggunakan sistem kontrol prediksi waktu kerja yang didasarkan pada jumlah orang di dalam ruangan. Hasil yang didapatkan dengan kontrol prediktif tersebut, suhu dalam ruangan berhasil dijaga stabil pada suhu nyaman yaitu antara $24,6^{\circ} \mathrm{C}$ sampai $27,1^{\circ} \mathrm{C}$.
\end{abstract}

\section{Kata Kunci : Pendingin Ruangan, Kontrol Prediktif dan Arduino}

\begin{abstract}
Air Conditioning (AC) is used every day in buildings. AC dominates energy consumption of a building. This research aims to reduce $\mathrm{AC}$ energy consumption by controlling the room temperature between $22,8^{\circ} \mathrm{C}$ to $27,1^{\circ} \mathrm{C}$. The air conditioning machine is controlled by a working time predictive system that based on number of people in the room. The predictive control is success in maintained room temperature in comfortable temperature i.e. between $24,6^{\circ} \mathrm{C}$ to $27,1^{\circ} \mathrm{C}$.
\end{abstract}

Keywords : Air Conditioning, Predictive Control and Arduino

\section{Pendahuluan}

Pendingin ruangan atau Air Conditioner (AC) memiliki banyak sekali variasi, fungsi, dan bentuk, yang dalam hal ini disesuaikan pada bentuk dan kapasitas besarnya ruangan yang akan menggunakan fasilitas pendingin ruangan tersebut. Suhu ruangan nyaman, untuk orang Indonesia berada pada rentang $22,8^{\circ} \mathrm{C}-25,8^{\circ} \mathrm{C}$ untuk suhu nyaman optimal dan $25,8^{\circ} \mathrm{C}-27,1^{\circ} \mathrm{C}$ untuk suhu hangat nyaman [1].

Penggunaan sistem kontrol sangat membantu dalam menurunkan konsumsi energi pada mesinmesin pendingin [2]. Pada penelitian tersebut, sistem dapat menurunkan konsumsi listrik sebesar $11 \%$ dibandingkan ketika menggunakan sistem konvensional. Penghematan tersebut dicapai dengan cara memodifikasi peralatan kontrol mesin AC dengan tambahan Variable Speed Drive (VSD) untuk merubah kecepatan kompresor dan dikontrol dengan fuzzy logic. Saat ini harga VSD masih mahal, sehingga perlu alternatif sistem kontrol lain untuk mengontrol pendingin ruangan.

Menurut Dani Kurnianto dkk [3] penggunaan sistem kontrol pada rumah (Smart Home) sangat membantu dalam pengurangan energi listrik. Alternatif sistem kontrol yang murah dan mudah kita dapatkan adalah dengan Arduino Uno sebagai otak kontroler. Untuk memudahkan pertukaran data sistem wireless sangat dimungkinkan diterapkan untuk pengontrolan dengan menggunakan Arduino uno [4].

Banyak sistem kontrol yang dapat digunakan untuk menghemat energi pada pendingin ruangan (AC). Salah satu alternatif yang murah dan efisien adalah dengan menghitung beban pendinginan ruangan. Penelitian ini bertujuan memprediksi waktu kerja mesin pendingin ruangan berdasarkan jumlah orang yang berada di dalam ruangan, sehingga kerja mesin pendingin dapat lebih efisien dari sistem konvensional. Pada penelitian ini dilakukan perancangan dan uji performansi sistem control prediktif dengan menghitung beban 
pendinginan (orang) dalam ruangan dengan memanfaatkan sensor inframerah. Selain itu, untuk mengurangi penggunaan kabel, sistem dilengkapi dengan peralatan komunikasi data secara wireless.

\section{Tinjauan Pustaka}

\subsection{Siklus Mesin Kompresi Uap.}

Sistem kompresi uap merupakan dasar sistem refrigerasi yang terbanyak digunakan, dengan komponen utamanya adalah kompresor, evaporator, alat ekspansi (Throttling Device), dan kondensor. Keempat komponen tersebut melakukan proses yang saling berhubungan dan membentuk siklus refrigerasi kompresi uap. Pada sistem ini juga terdapat refrigeran atau fluida yang digunakan sebagai media penyerap panas dari kabin atau ruangan yang dikondisikan ke dalam sistem, kemudian dihantarkan dan membuang panas tersebut ke lingkungan. Sistem yang terjadi pada sistem refrigerasi kompresi uap merupakan sistem tertutup sebagaimana ditunjukkan pada gambar $1[5]$.

\subsection{Pendingin Ruangan}

AC adalah suatu mesin yang memiliki fungsi sebagai pendingin udara yang berada di sekitar mesin pendingin tersebut. Secara khusus pengertian dari AC (Air Conditioner) adalah suatu mesin yang di gunakan untuk mendinginkan udara dengan cara mensirkulasikan gas refrigerant berada di pipa yang di tekan dan di hisap oleh kompresor.

Adapun sebab mengapa gas refrigerant di pilih sebagai bahan yang di sirkulasikan, yaitu karena bahan ini mudah menguap dan bentuknya bisa berubah-ubah, yaitu cairan atau gas. Panas yang berada pada pipa kondensor berasal dari gas refrigerant yang di tekan oleh kompressor sehingga bahan tersebut menjadi panas dan pada bagian Expantion Valve pipa tempat sirkulasi gas refrigerant di perkecil, sehingga tekanannya semakin meningkat dan pada pipa evaporator menjadi dingin.

Prinsip kerja pada AC Split adalah dimulai dari kompresor. Kompresor memompa gas yang bertekanan tinggi dan bersuhu tinggi melalui pipa tekan (Discharge) ke kondensor. Di dalam kondensor suhu gas yang tinggi dibuang oleh Fan yang terletak pada Unit outdoor, sehingga suhu gas refrigerant menjadi dingin. Setelah melalui kondensor gas refrigerant masuk ke Filter Dryer untuk disaring, agar gas yang mengalir tidak terdapat kotoran. Setelah disaring gas (Freon) masuk ke pipa kapiler yang lubangnya begitu kecil, di dalam pipa ini freon saling bertubrukan dan berdesak-desakan disini freon telah berubah wujud menjadi cair yang sebelumnya berupa gas. Setelah melewati pipa kapiler freon akan menguap dan mengambil panas didalam Evaporator yang hampa udara. Sehingga pipa-pipa di evaporator menjadi dingin dan dihembuskan oleh fan motor yang ada dalam Indoor unit.

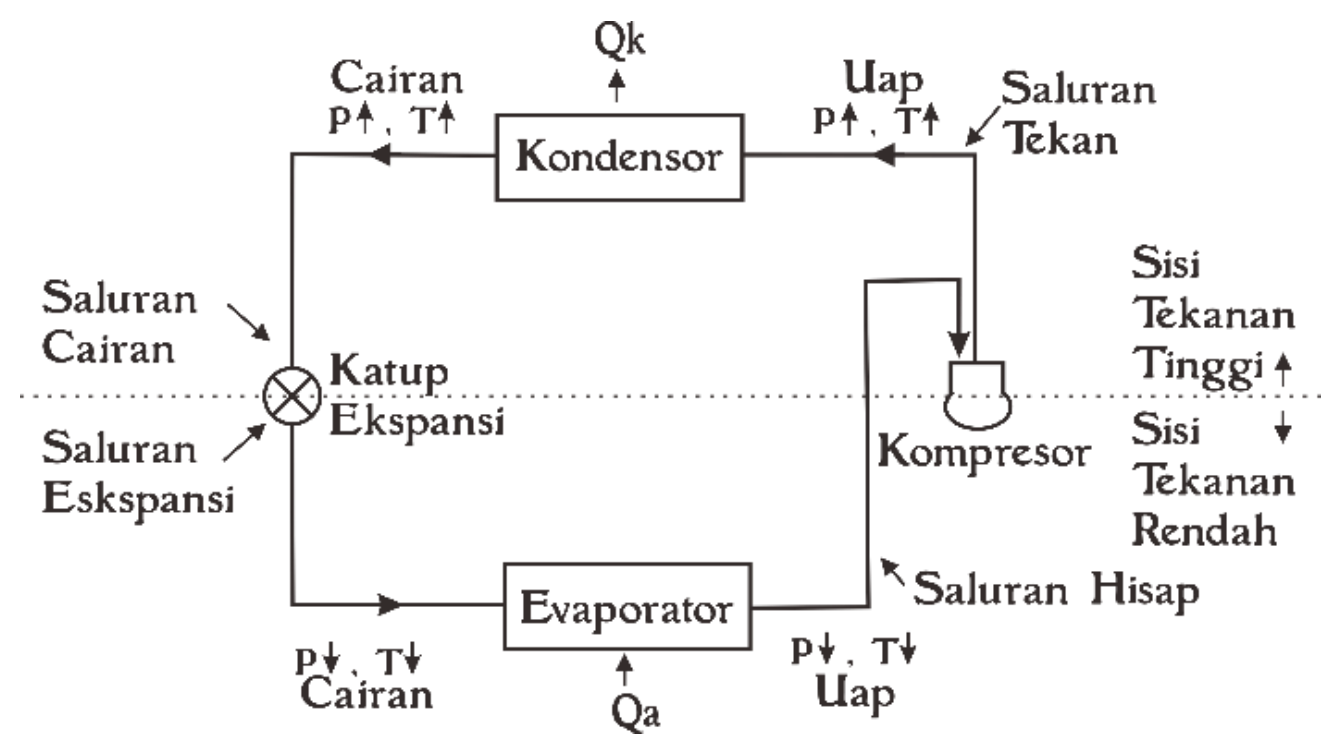

Gambar 1. Siklus Mesin Kompresi Uap [5] 
Setelah melakukan proses pendinginan freon di dalam evaporator, freon kembali disedot masuk kembali melalui pipa hisap (suction) ke dalam Kompresor. Begitulah cara kerja AC, singkatnya freon dipompa oleh kompresor keluar melalui pipa tekan lalu masuk ke kondensor lalu ke filter dryer kemudian masuk melalui pipa kapiler menuju evaporator dan kembali ke kompresor melalui pipa hisap (Suction). Proses ini terus berulang ketika AC digunakan [6].

\subsection{Arduino Uno}

Arduino UNO adalah sebuah board mikrokontroler yang didasarkan pada ATmega328 (datasheet). Arduino UNO mempunyai 14 pin digital input/output (6 di antaranya dapat digunakan sebagai output PWM), 6 input analog, sebuah osilator kristal $16 \mathrm{MHz}$, sebuah koneksi USB, sebuah power jack, sebuah ICSP header, dan sebuat tombol reset. Arduino UNO memuat semua yang dibutuhkan untuk menunjang mikrokontroler, mudah menghubungkannya ke sebuah komputer dengan sebuah kabel USB atau mensuplainya dengan sebuah adaptor $\mathrm{AC}$ ke DC atau menggunakan baterai untuk memulainya [7].

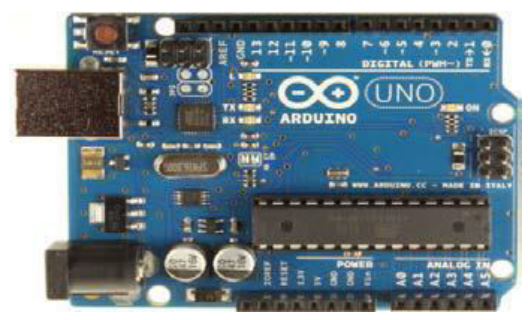

Gambar 2. Arduino Uno

\subsection{Light Depending Resistor (LDR)}

LDR adalah sebagai salah satu komponen listrik yang peka cahaya, piranti ini bisa disebut juga sebagai fotosel, fotokonduktif atau fotoresistor. LDR memanfaatkan bahan semikonduktor yang karakteristik listriknya berubah-ubah sesuai dengan cahaya yang diterima. Bahan yang digunakan adalah Kadmium Sulfida (CdS) dan Kadmium Selenida (CdSe). Bahan-bahan ini paling sensitif terhadap cahaya dalam spektrum tampak, dengan puncaknya sekitar $0,6 \mu \mathrm{m}$ untuk CdS dan 0,75 $\mu$ m untuk CdSe. Sebuah LDR CdS yang tipikal memiliki resistansi sekitar $1 \mathrm{M} \Omega$ dalam kondisi gelap gulita dan kurang dari $1 \mathrm{~K} \Omega$ ketika ditempatkan dibawah sumber cahaya terang. Dengan kata lain, resistansi LDR sangat tinggi dalam intensitas cahaya yang lemah (gelap), sebaliknya resistansi LDR sangat rendah dalam intensitas cahaya yang kuat (terang) [8].

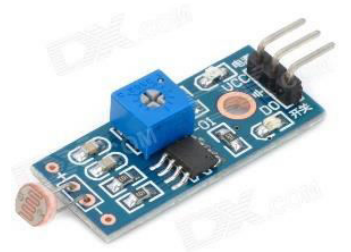

\section{Gambar 3. Modul LDR}

\subsection{Laser Inframerah}

Laser inframerah adalah suatu perangkat yang memancarkan sinyal merah berupa titik sampai jarak tertentu. Bekerja dengan tegangan 3 sampai $5 \mathrm{vdc}$.

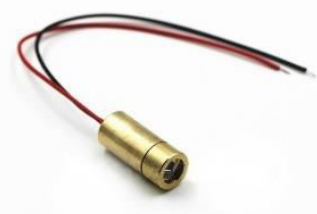

Gambar 4. Laser Inframerah

\subsection{NRF24L01}

Modul nirkabel NRF24L01 adalah sebuah modul komunikasi yang memanfaatkan gelombang RF $2,4 \mathrm{GHz}$ ISM (Industrial, Scientific and Medical). Modul ini menggunakan antarmuka SPI (Serial Peripheral Interface) untuk berkomunikasi. NRF24L01 mengintegrasikan pengirim lengkap $2.4 \mathrm{GHz} \mathrm{RF}$, RF pengumpul, dan akselerator protokol berupa Enhanced Shockburst yang mendukung antarmuka SPI kecepatan tinggi untuk kontroler aplikasi. NRF24L01 memiliki solusi terkait daya berupa daya ultra rendah yang memungkinkan daya tahan baterai berbulan-bulan. Modul ini dapat digunakan untuk pembuatan perangkat tambahan komputer, piranti permainan, piranti fitnes dan olahraga, mainan anak-anak dan alat lainnya [9]. 


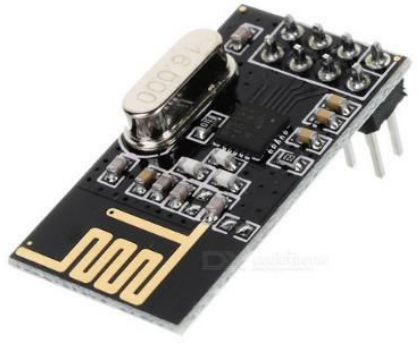

Gambar 5. Modul NRF24L01

\section{Metoda}

Pada penelitian ini digunakan AC Split 1 PK. Sistem kontrol yang kami gunakan adalah memodifikasi peralatan kontrol yang ada pada AC tersebut mengunakan Arduino.

Sensor inframerah dipasang didepan pintu masuk sebagai alat untuk menghitung jumlah orang yang masuk ke dalam ruangan yang merupakan beban bagi pendinginan ruangan. Setelah didapat data jumlah orang yang berada didalam ruangan, sistem kontrol akan memprediksi waktu kerja mesin pendingin ruangan agar suhu ideal dalam ruangan tercapai. Sistem prediksi akan mengaktifkan mesin AC dengan melakukan sistem on-off pada unit outdoor dari AC (kompresor dan fan kondensor). Data diambil untuk 3 kondisi yaitu, kondisi 1 orang berada dalam ruangan, kondisi 2 orang berada dalam ruangan, terakhir kondisi 3 orang berada dalam ruangan. Kontrol on-off berdasarkan waktu yang dibutuhkan untuk mencapai temperatur nyaman optimal $22,8^{\circ} \mathrm{C}-25,8^{\circ} \mathrm{C}$ dan suhu hangat nyaman $25,8^{\circ} \mathrm{C}-27,1^{\circ} \mathrm{C}$ [1]. Ruangan yang digunakan adalah $4 \mathrm{~m} \times 5 \mathrm{~m}$, bertempat di Lab Teknik Pendingin dan Tata Udara

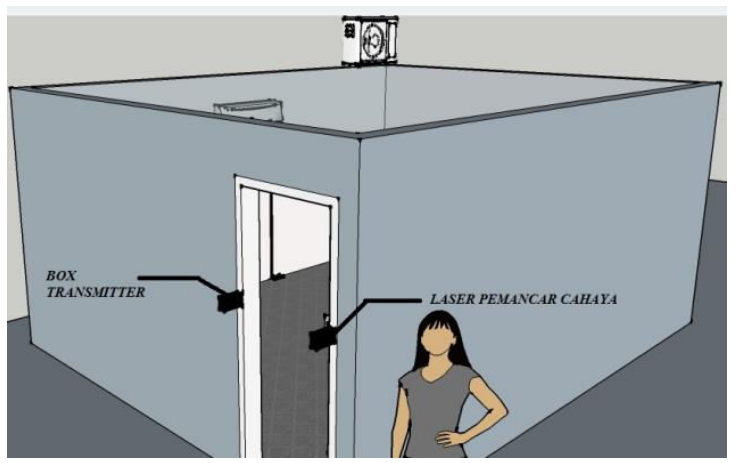

Gambar 6. Ruangan yang dikontrol

Terdapat 3 komponen dasar pengontrolan pada sistem ini, yaitu proses Input untuk menerima masukan data yang akan diproses oleh Arduino.
Input dari sistem ini adalah nilai counter yang dideteksi dari modul LDR. Modul LDR akan membaca nilai counter manusia dan mengirimnya ke Arduino, jika seseorang melewati sensor LDR 1 kemudian melewati LDR 2 maka sistem akan membaca penambahan orang $(+1)$, sedangkan sebaliknya maka sistem akan membaca pengurangan orang (-1).

Arduino akan mengirimkan data Input ke sistem penerima dengan menggunakan modul NRF24L01, Aktuator akan mengaktifkan (on) atau mematikan (off) mesin pendingin. Lebih lengkapnya bisa dilihat di Gambar 7.

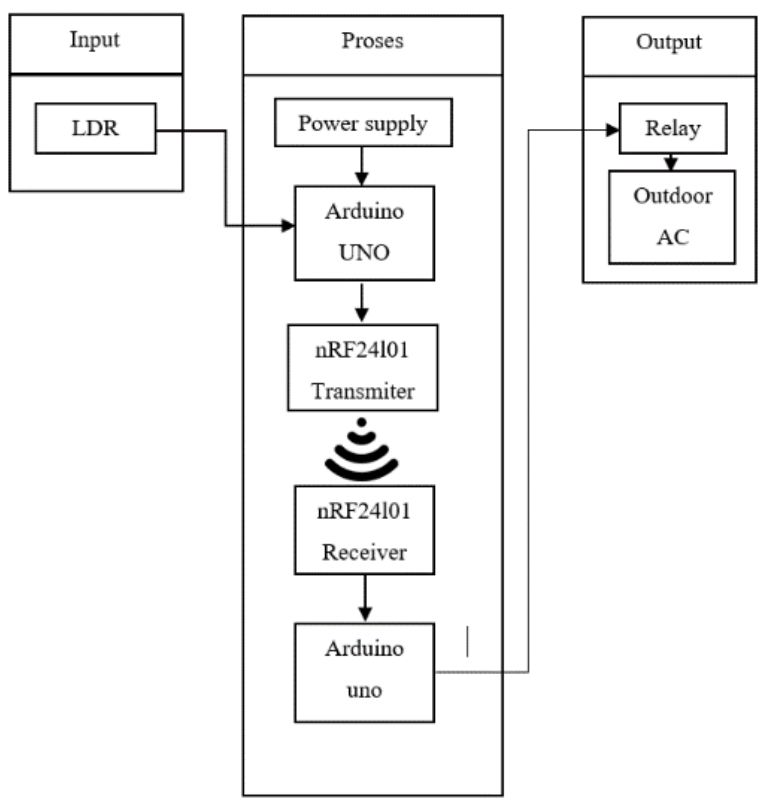

Gambar 7. Sistem Kontrol Prediktif

\section{Hasil dan Pembahasan}

Pengambilan data percobaan untuk mengetahui waktu yang dibutuhkan untuk mencapai temperatur nyaman manusia di Indonesia dengan beban 1 orang. Dengan program jika temperatur ruangan kecil dari $25^{\circ} \mathrm{C}$ unit outdoor (kompresor dan fan) akan mati dan jika temperatur pada ruangan lebih besar dari $27^{\circ} \mathrm{C}$ outdoor akan menyala. Hasilnya dapat dilihat pada gambar 8 . 


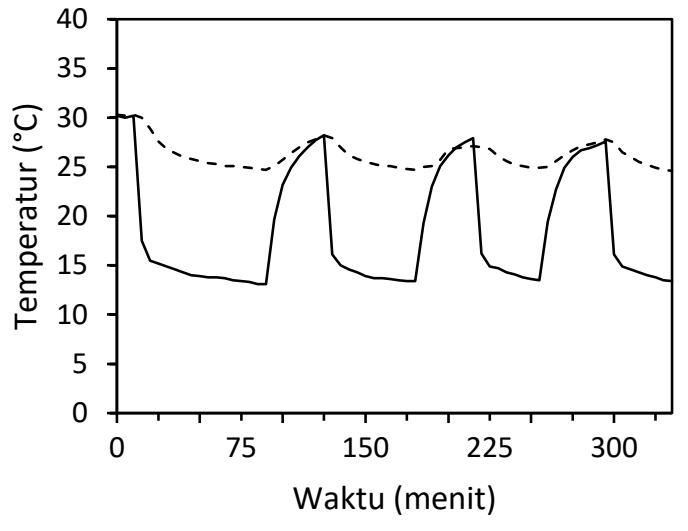

- - - T. Ruangan — T. Evap

Gambar 8. Data Percobaan 1 orang dalam ruangan

Berdasarkan hasil percobaan tersebut didapatkan kesimpulan,

- Dari temperatur ruangan awal $30,3^{\circ} \mathrm{C}$ mencapai $24,9^{\circ} \mathrm{C}$ membutuhkan waktu 80 menit.

- Dari temperatur $24,9^{\circ} \mathrm{C}$ mencapai $27^{\circ} \mathrm{C}$ membutuhkan waktu 30 menit.

- Dari temperatur $27^{\circ} \mathrm{C}$ mencapai $24,9^{\circ} \mathrm{C}$ membutuhkan waktu 50 menit.

- Dari temperatur $24,9^{\circ} \mathrm{C}$ mencapai $27^{\circ} \mathrm{C}$ membutuhkan waktu 30 menit.

- Dari temperatur $27,1^{\circ} \mathrm{C}$ mencapai $24,9^{\circ} \mathrm{C}$ membutuhkan waktu 40 menit.

- Dari temperatur $24,9^{\circ} \mathrm{C}$ mencapai $27,1^{\circ} \mathrm{C}$ membutuhkan waktu 30 menit.

- Dari temperatur $27,1^{\circ} \mathrm{C}$ mencapai $24,9^{\circ} \mathrm{C}$ membutuhkan waktu 35 menit.

Data yang diperoleh ini menjadi tolak ukur untuk kontrol temperatur prediktif dengan kondisi beban 1 orang sebagai berikut:

- Unit outdoor (kompresor dan fan kondensor) menyala awal dengan waktu 80 menit.

- Unit outdoor mati dengan waktu 30 menit.

- Unit outdoor menyala dengan waktu 50 menit.

- Unit outdoor mati dengan waktu 30 menit.

- Unit outdoor menyala dengan waktu 40 menit.

- Unit outdoor mati dengan waktu 30 menit.

- Unit outdoor menyala dengan waktu 35 menit.

- Selanjutnya Unit outdoor akan mati 30 menit dan menyala 40 menit secara berulang.

Pengambilan data kedua dilakukan untuk beban pendinginan dua orang. Hasilnya bisa dilihat pada gambar 9.

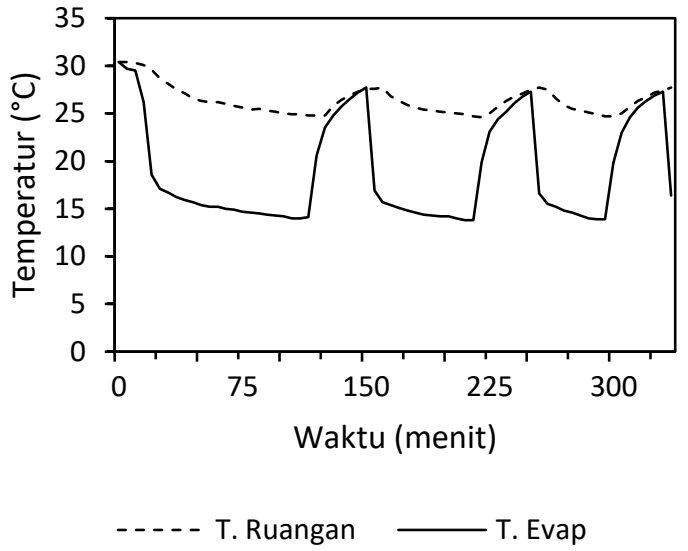

Gambar 9. Data Percobaan 2 orang dalam ruangan

Berdasarkan hasil percobaan tersebut didapatkan kesimpulan,

- Dari temperatur ruangan awal $30,4^{\circ} \mathrm{C}$ mencapai $24,9^{\circ} \mathrm{C}$ membutuhkan waktu 105 menit.

- Dari temperatur $24,8^{\circ} \mathrm{C}$ mencapai $27,3^{\circ} \mathrm{C}$ membutuhkan waktu 25 menit.

- Dari temperatur $27,6^{\circ} \mathrm{C}$ mencapai $24,9^{\circ} \mathrm{C}$ membutuhkan waktu 60 menit.

- Dari temperatur $25^{\circ} \mathrm{C}$ mencapai $27,1^{\circ} \mathrm{C}$ membutuhkan waktu 25 menit.

- Dari temperatur $27,7^{\circ} \mathrm{C}$ mencapai $24,7^{\circ} \mathrm{C}$ membutuhkan waktu 50 menit.

- Dari temperatur $25^{\circ} \mathrm{C}$ mencapai $27,2^{\circ} \mathrm{C}$ membutuhkan waktu 25 menit.

Dengan demikian dapat menjadi tolak ukur untuk kontrol temperatur prediktif dengan kondisi beban 2 orang sebagai berikut:

- Unit outdoor menyala awal dengan waktu 105 menit.

- Unit outdoor mati dengan waktu 25 menit.

- Unit outdoor menyala dengan waktu 60 menit.

- Unit outdoor mati dengan waktu 25 menit.

- Unit outdoor menyala dengan waktu 50 menit.

- Unit outdoor mati dengan waktu 25 menit.

- Selanjutnya Unit outdoor akan mati 25 menit dan menyala 50 menit secara berulang.

Pengambilan data ketiga dilakukan untuk beban pendinginan tiga orang. Hasilnya bisa dilihat pada gambar 10. 


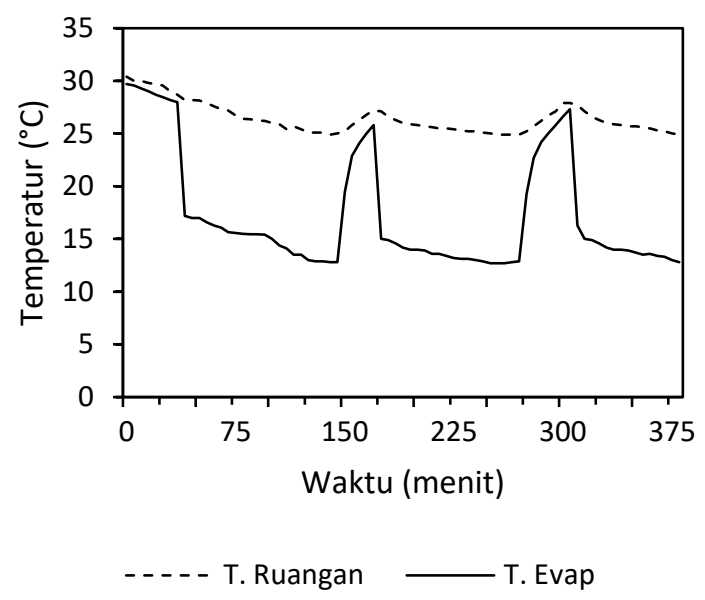

Gambar 10. Data Percobaan 3 orang dalam ruangan

Berdasarkan hasil percobaan tersebut didapatkan kesimpulan,

- Dari temperatur ruangan awal $30,4^{\circ} \mathrm{C}$ mencapai $24,9^{\circ} \mathrm{C}$ membutuhkan waktu 140 menit.

- Dari temperatur $25,8^{\circ} \mathrm{C}$ mencapai $27,2^{\circ} \mathrm{C}$ membutuhkan waktu 20 menit.

- Dari temperatur $26,6^{\circ} \mathrm{C}$ mencapai $24,9^{\circ} \mathrm{C}$ membutuhkan waktu 80 menit.

- Dari temperatur $25,7^{\circ} \mathrm{C}$ mencapai $27,1^{\circ} \mathrm{C}$ membutuhkan waktu 20 menit.

- Dari temperatur $26,6^{\circ} \mathrm{C}$ mencapai $24,9^{\circ} \mathrm{C}$ membutuhkan waktu 65 menit.

Dengan demikian dapat menjadi tolak ukur untuk kontrol temperatur prediktif dengan kondisi beban 3 orang sebagai berikut:

- Unit outdoor menyala awal dengan waktu 140 menit.

- Unit outdoor mati dengan waktu 20 menit.

- Unit outdoor menyala dengan waktu 80 menit.

- Unit outdoor mati dengan waktu 20 menit.

- Unit outdoor menyala dengan waktu 65 menit.

- Selanjutnya Unit outdoor akan mati 20 menit dan menyala 75 menit secara berulang.

Setelah mengetahui setting waktu, dilakukan ujicoba sistem kontrol prediktif pada mesin pendingin tersebut. Didapatkan hasil seperti gambar 11 .

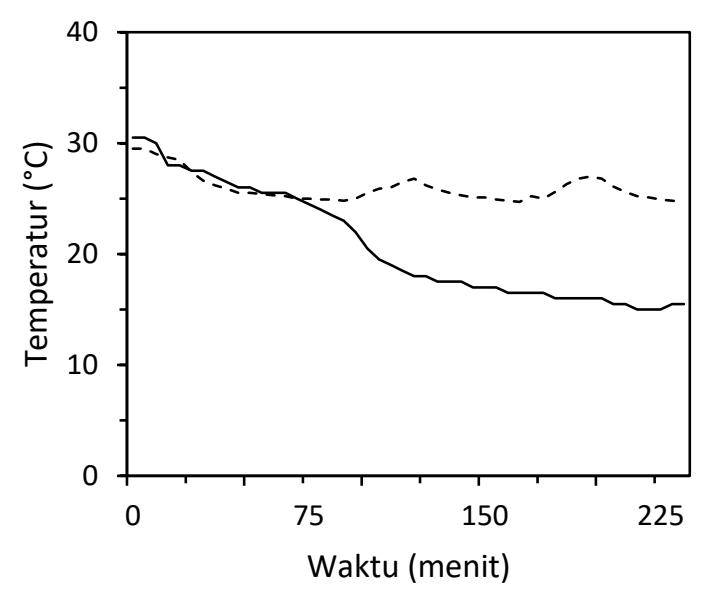

T. Ruangan sebelum menggunakan kontrol
- - - - T. Ruangan sesudah menggunakan kontrol

Gambar 11. Perbandingan Suhu ruangan dengan beban 1 orang

Dari Gambar 11 dapat dilihat perbedaan dari sistem menggunakan kontrol dan tidak menggunakan kontrol. Jika tidak menggunakan control, temperatur ruang mencapai $15^{\circ} \mathrm{C}$ yang mengakibatkan temperatur ruang yang tidak nyaman. Sedangkan temperatur ruang yang sudah menggunakan kontrol hanya mencapai minimum $24,5^{\circ} \mathrm{C}$ yang masih termasuk temperatur nyaman Indonesia.

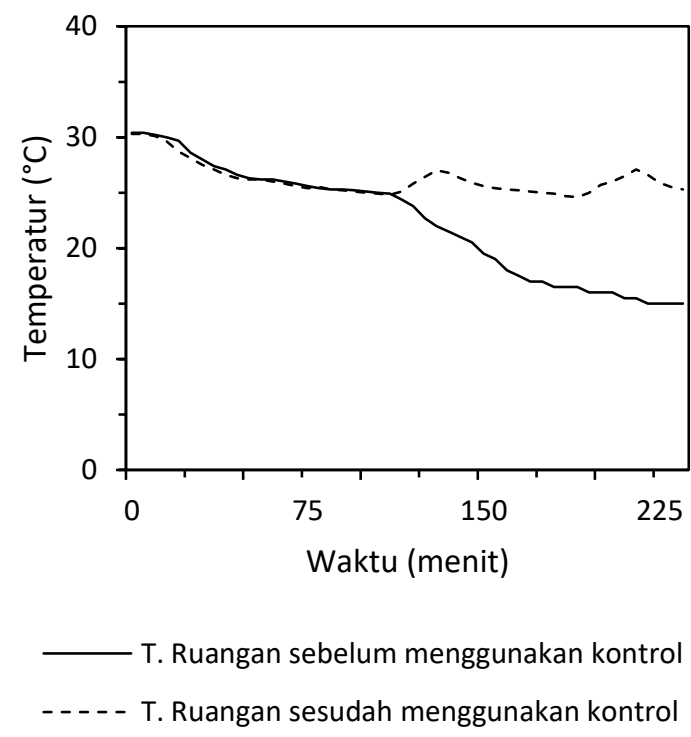

Gambar 12. Perbandingan Suhu ruangan dengan beban 2 orang

Dari Gambar 12 dapat dilihat perbedaan dari sistem menggunakan kontrol dan tidak menggunakan kontrol. Jika tidak menggunakan 
kontrol temperatur ruang mencapai $15^{\circ} \mathrm{C}$ yang mengakibatkan temperatur ruang yang tidak nyaman. Sedangkan temperatur ruang yang sudah menggunakan kontrol hanya mencapai minimum $24,6^{\circ} \mathrm{C}$ yang masih termasuk temperatur nyaman Indonesia.

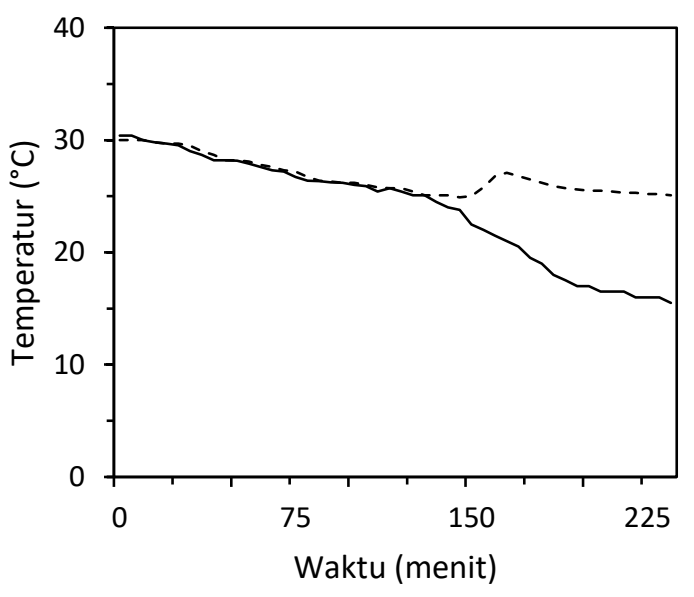

- T. Ruangan sebelum menggunakan kontrol

- - - - T. Ruangan sesudah menggunakan kontrol

Gambar 13. Perbandingan Suhu ruangan dengan beban 3 orang

Dari Gambar 13 dapat dilihat perbedaan dari sistem menggunakan kontrol dan tidak menggunakan kontrol. Jika tidak menggunakan kontrol temperatur ruang mencapai $15,5^{\circ} \mathrm{C}$ yang mengakibatkan temperatur ruang yang tidak nyaman. Sedangkan temperatur ruang yang sudah menggunakan kontrol hanya mencapai minimum $24,9^{\circ} \mathrm{C}$ yang masih termasuk temperatur nyaman Indonesia.

\section{Kesimpulan}

Penggunaan kontrol prediktif pada mesin pendingin ruangan $(\mathrm{AC})$ dapat mempertahankan suhu ruangan selalu pada kondisi nyaman yaitu $24,6^{\circ} \mathrm{C}$ sampai $27,1^{\circ} \mathrm{C}$. Adapun waktu yang dibutuhkan untuk mencapai kondisi nyaman untuk masing-masing beban 1-3 orang berbeda antara 80140 menit.

\section{Ucapan Terima Kasih (Acknowledgement)}

Ucapan terima kasih ditujukan Politeknik Negeri Indramayu yang telah membiayai penelitian dengan skema Penelitian Internal.

\section{Daftar Pustaka}

[1] B. S. N. BSN, "Tata cara perancangan sistem ventilasi dan pengkondisian udara pada bangunan gedung." Badan Standardisasi Nasional, 08-Aug-2001.

[2] Sudirman -, I. G. B. W. Kusuma, and M. Sucipta, "Studi Eksperimental Pengontrolan Air Conditioning System Dengan Fuzzy Logic Control," J. Energi Dan Manufaktur, 2011.

[3] D. Kurnianto, A. M. Hadi, and E. Wahyudi, "Perancangan Sistem Kendali Otomatis pada Smart Home menggunakan Modul Arduino Uno," J. Nas. Tek. ELEKTRO, vol. 5, no. 2, pp. 260-270, Jul. 2016.

[4] S. Shafiudin, F. J. Rohma, A. E. Prasetya, and R. Firmansyah, "Pemantauan Ruang Inkubator Penetasan Telur Ayam Dengan Berbasis Telemetri Menggunakan Arduino Uno R3," $J$. Nas. Tek. ELEKTRO, vol. 5, no. 1, pp. 26-35, Mar. 2016.

[5] R. J. Dossat and T. J. Horan, Principles of Refrigeration, 5 edition. Upper Saddle River, N.J: Pearson, 2001.

[6] E. Karyanto; Penuntun praktikum: TEKNIK MESIN PENDINGIN (PERKAKASPENGISIAN, BRAZING, ARUS PUTAR , STATIKSHOW CASE). Restu Agung, 2004.

[7] Y. M. Dinata;, Arduino Itu Pintar. Elex Media Komputindo, 2016.

[8] A. K. Tsauqi et al., "SAKLAR OTOMATIS BERBASIS LIGHT DEPENDENT RESISTOR (LDR) PADA MIKROKONTROLER ARDUINO UNO," Pros. Semin. Nas. Fis. E-J., vol. 5, pp. SNF2016-CIP-19-24, Oct. 2016.

[9] D. I. Af'idah, A. F. Rochim, and E. D. Widianto, "Perancangan Jaringan Sensor Nirkabel (JSN) untuk Memantau Suhu dan Kelembaban Menggunakan nRF24L01+," $J$. Teknol. Dan Sist. Komput., vol. 2, no. 4, pp. 267-276, Oct. 2014.

\section{Biodata Penulis}

Rofan Aziz, Dosen Politeknik Negeri Indramayu yang tergabung dalam Control Instrumentation and Smart Energy Management Research Group (CISEMAR GROUP). 
Agung Kamaluddin, Mahasiswa Politeknik Negeri Indramayu yang tergabung dalam Control Instrumentation and Smart Energy Management Research Group (CISEMAR GROUP).
Karsid, Dosen Politeknik Negeri Indramayu yang tergabung dalam Control Instrumentation and Smart Energy Management Research Group (CISEMAR GROUP). 